\title{
(6) OPEN ACCESS \\ Psychological interventions for mental health disorders in children with chronic physical illness: a systematic review
}

\author{
Sophie Bennett, ${ }^{1}$ Roz Shafran, ${ }^{1}$ Anna Coughtrey, ${ }^{2}$ Susan Walker, ${ }^{1,2}$ Isobel Heyman ${ }^{1,2}$
}

\begin{abstract}
- Additional material is published online only. To view please visit the journal online (http://dx.doi.org/10.1136/ archdischild-2014-307474).

${ }^{1}$ UCL Institute of Child Health, University College London, London, UK

${ }^{2}$ Great Ormond Street Hospital for Children NHS Foundation Trust, London, UK
\end{abstract}

\section{Correspondence to}

Sophie Bennett, UCL Institute of Child Health, London WC1N 1EH, UK; sophie.bennett.10@ ucl.ac.uk

Received 2 September 2014 Revised 13 February 2015 Accepted 16 February 2015



\section{SLinked}

- http://dx.doi.org/10.1136/ archdischild-2014-307866

\section{CrossMark}

\section{To cite: Bennett $S$,}

Shafran R, Coughtrey A,

et al. Arch Dis Child

2015:100:308-316.

\section{ABSTRACT \\ Background Children with chronic physical illness are significantly more likely to develop common psychiatric symptoms than otherwise healthy children. These children therefore warrant effective integrated healthcare yet it is not established whether the known, effective, psychological treatments for symptoms of common childhood mental health disorders work in children with chronic physical illness.}

Methods EMBASE, MEDLINE, PsycINFO and CINAHL databases were searched with predefined terms relating to evidence-based psychological interventions for psychiatric symptoms in children with chronic physical illness. We included all studies (randomised and non-randomised designs) investigating interventions aimed primarily at treating common psychiatric symptoms in children with a chronic physical illness in the review. Two reviewers independently assessed the relevance of abstracts identified, extracted data and undertook quality analysis. Results Ten studies (209 children, including 70 in control groups) met the criteria for inclusion in the review. All studies demonstrated some positive outcomes of cognitive behavioural therapy for the treatment of psychiatric symptoms in children with chronic physical illness. Only two randomised controlled trials, both investigating interventions for symptoms of depression, were found. Conclusions There is preliminary evidence that cognitive behavioural therapy has positive effects in the treatment of symptoms of depression and anxiety in children with chronic physical illness. However, the current evidence base is weak and fully powered randomised controlled trials are needed to establish the efficacy of psychological treatments in this vulnerable population.

\section{INTRODUCTION}

Rates of psychiatric disorder are up to four times greater in children with chronic physical illness than in children who are physically well. ${ }^{1-3}$ Psychiatric symptoms have considerable consequences for a child's quality of life, their behavioural, emotional, educational and social functioning, ${ }^{45}$ and mental ill health has, in turn, been shown to impact upon management and medical consequences of the physical illness. ${ }^{6-10}$ Delivery of effective psychological treatment to this population is therefore a priority. In the UK, government bodies such as the National Health Service (NHS) Confederation have highlighted the social, health and economic benefits that arise from integration of physical and mental health treatments. ${ }^{11}$ The US National Center for Chronic Disease Prevention and Health Promotion's 'Public Health Action Plan to Integrate Mental Health Promotion and Mental Illness Prevention with
Chronic Disease Prevention', ${ }^{12}$ similarly includes an objective to develop strategies for integrating mental health and mental illness and public health systems.

There are highly effective evidence-based psychological treatments for some of the common psychiatric disorders in children and young people. ${ }^{13}$ However, guidelines regarding evidence-based interventions for common mental health disorders in children with physical illness are scarce, and in many cases there remains a large unmet need. For example one study ${ }^{14}$ found that of 114 children with epilepsy, $61 \%$ had psychiatric diagnoses, but, of these, only $33 \%$ had received treatment, despite regularly attending clinics for their epilepsy. Clinicians do not have adequate guidance to support them in making decisions regarding effective interventions in this population and thus children are not able to access appropriate and timely interventions for their mental health disorder. ${ }^{1415}$

It appears that children with physical and mental health conditions are viewed as complex; the care of their physical health may be prioritised, inadvertently leading to neglect of their mental health needs. If clinicians who work with children in mental health and paediatric services are aware of the effectiveness of mental health treatments in this population, and the best ways for families to access them, then services can be organised to meet the need. It is inequitable that at the present time children who are already disadvantaged by their physical illnesses are not able to access appropriate services.

This systematic review therefore aimed to investigate the evidence for the effectiveness of psychological therapies for symptoms of common mental health disorders in children and young people with chronic physical illnesses. In addition, we aimed to conduct a meta-analysis of the findings if the data were appropriate. Finally, the review aimed to understand any key factors associated with the success of an intervention and the ability of children/young people to access it.

\section{METHODS}

Systematic review methods were used in accordance with Cochrane guidelines. ${ }^{15 a}$

\section{Search methods}

Electronic Searches, citation searches, reference list searches and grey literature searches were independently undertaken by AC and SB.

\section{Electronic searches}

EMBASE, MEDLINE, PsycINFO and CINAHL databases were searched from inception to 
February 2014. Grey/unpublished literature was also included, through searches of Google and Google Scholar. Broadly, the search terms were categorised into three primary areas; (1) Chronic illness, (2) Impairing psychiatric symptoms, (3) Psychotherapeutic intervention. See online supplementary appendix 1 for full list of search terms.

\section{Other search resources}

Citation lists and reference lists of identified papers were also searched for relevant papers. Additional literature was found through personal contact with researchers in the area.

\section{Inclusion criteria}

Study eligibility criteria were:

(1) Randomised controlled trials (RCTs), controlled trials, cohort studies, case control studies and multiple-baseline studies; (2) Studied participants aged $0-18$ years with a chronic physical illness and symptoms of mental health disorder (anxiety, depression or disruptive behaviour symptoms; defined by Diagnostic and Statistical Manual of Mental Disorders IV $^{16}$ and Diagnostic and Statistical Manual of Mental Disorders $5^{17}$ ); (3) Reported a childrelated mental health measure as the primary outcome (The measure had to relate to the mental health of the child and not the parent/carer, although parent-reports of child health/behaviour were acceptable); (4) Studied a psychotherapeutic intervention (defined as an intervention in which a therapist purposively and systematically attempts to influence a patient by psychological means so that the patients' symptoms decrease or there is a positive change in behaviour'; as used in Yorke et al, 2007 ${ }^{18}$ ). At present, there is no consensus regarding the definition of chronic physical illness. Van der Lee et $a l^{19}$ conducted a systematic review of the definitions and measurement of chronic illness, and found three commonly used definitions for 'chronic illness' or 'chronic health conditions' (those of Pless and Douglas ${ }^{20}$; Perrin et $a l^{21}$ and Stein et $a l^{22}$ ). All define chronic physical illnesses as lasting for at least 3 months (some define longer periods) and causing functional impairment. As definitions vary, so too do the lists of possible conditions that fall under these definitions. We derived our list of illnesses (and thus search terms) from those used in previous reviews of chronic physical illnesses in children. ${ }^{23}$ Conditions included: AIDS and HIV, asthma, cancer, chronic fatigue syndrome, cleft palate, cystic fibrosis, deafness/hearing impairment, diabetes, epilepsy, heart disease, inflammatory bowel disease (IBD), kidney disease, liver disease, migraine, sickle cell anaemia, spina bifida and visual impairment.

\section{Exclusion criteria}

We excluded those interventions that had a primary aim of increasing self-efficacy or treatment adherence related to the physical illness. Additionally, we excluded papers where the psychiatric symptoms were directly related to the physical illness, such as interventions for anxious breathing in asthma. We excluded children who were 'survivors of cancer', as under definitions of chronic physical illness, it is not clear that this is a current illness, causing functional impairment within the last 3 months. We also excluded chronic pain (including headache), in line with previous reviews ${ }^{23}$ and as this has been the topic of a recent distinct Cochrane review. $^{24}$

\section{Data collection and analysis}

Study selection

Study selection was performed independently by two reviewers (AC and SB). Where disagreements arose about whether a study fitted with the inclusion criteria, this was resolved through discussion with RS as appropriate.

\section{Data extraction}

A data extraction form was developed, covering study characteristics and main results. Data was independently extracted by two reviewers (SB and SW). Data were inputted into EndNote X5 software.

\section{Methodological quality assessment}

Study quality was independently assessed by two reviewers (AC and SB) with the Effective Public Health Practice Project Quality Assessment Tool. ${ }^{25} 26$ This tool was chosen for its suitability in assessing a range of study designs within the area of public health research. Studies are rated as strong, moderate or weak, using predefined criteria, on a range of areas: selection bias, study design, confounders, blinding, data collection methods, withdrawals and dropouts. Total sample size is not considered. An overall total for study quality is also calculated by assessing the number of areas rated weakly (strong studies have no weak ratings, moderate ones have one weak rating and weak studies have two or more weak ratings).

\section{RESULTS}

The initial search identified 1966 independent papers. A total of 10 studies, and 2 follow-up studies, were found to fit with the criteria of the review. ${ }^{27-38}$ A total of 209 participants (173 participants with a chronic physical illness and impairing psychiatric symptoms), took part in the studies. See figure 1 for flow chart of study selection, tables 1 and 2 for summaries of included studies and table 3 for comprehensive recruitment figures.

All studies investigated interventions for anxiety or depression. Study participants included children with epilepsy $(n=2)$, IBD $(n=3)$, diabetes $(n=3)$, asthma $(n=1)$ and cystic fibrosis $(n=1)$. All interventions were based on a cognitive-behavioural framework; most had been previously used and evaluated in cohorts of children without a chronic physical illness. Two RCTs were found to fit with the criteria of the review. ${ }^{32} 37$ The remaining studies were non-randomised designs (see tables 1 and 2). Due to the range of study designs, it was not possible to conduct a meta-analysis.

\section{Quality assessment}

Within the bounds of the research design, studies were, for the most part, well executed, and 9 out of 10 studies were rated strongly or moderately with respect to quality (see online supplementary appendix 2). One rated weakly ${ }^{28}$, due to a lack of blinding, high rate of withdrawals/dropouts and the likely presence of selection bias of participants. No studies were rated 'strongly' with respect to blinding. As all studies demonstrated positive effects on mental health outcomes, it is not possible to analyse whether there is an association between methodological quality and study outcomes. However, we note that as this tool was designed to assess a range of study designs (randomised and non-randomised), it is possible for a study to rate strongly or moderately with respect to overall quality despite only moderate ratings across the categories (including study design). In addition, sample size is not accounted for and thus some strongly rated studies have small sample sizes and non-randomised designs. Positive study quality assessments therefore need to be interpreted with caution.

\section{Depression interventions}

All five depression interventions were 12-session cognitive behavioural therapy (CBT) protocols. Three studies 323537 used 


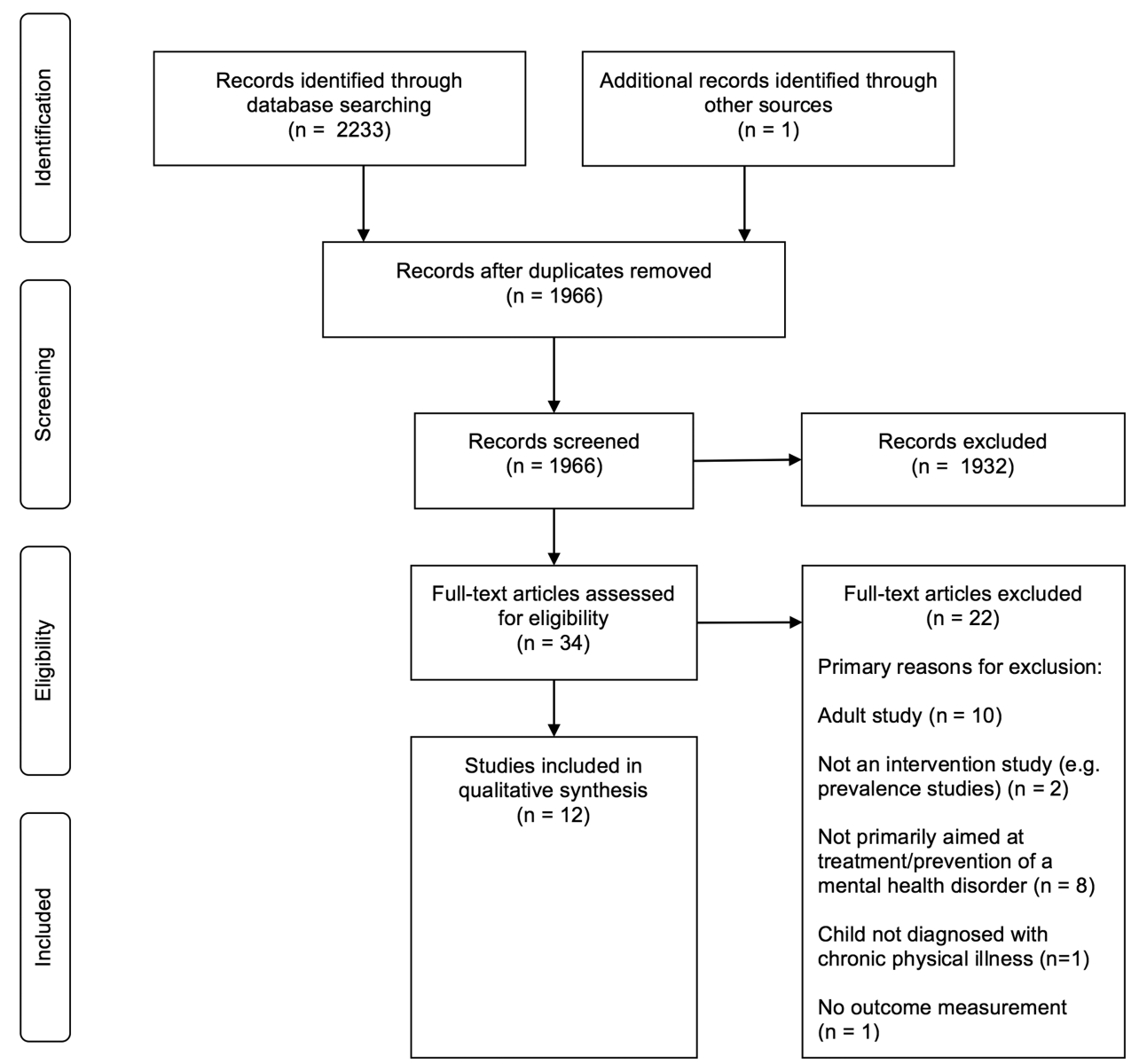

Figure 1 PRISMA 2009 flow diagram of literature search.

versions of protocols which have been well validated in children without physical illness (Treatment for Adolescents with Depression Study ${ }^{39}$ and Primary and Secondary Control Enhancement Training ${ }^{40}$ ). Standard CBT strategies were delivered, such as mood monitoring, problem solving and behavioural activation. One study reports ${ }^{34}$ on CBT delivered in a group format. Other programmes worked primarily one to one with the child. Szigethy et $a l^{35} 36$ also offered three family sessions of $60 \mathrm{~min}$; $40 \mathrm{~min}$ with the parents alone and $20 \mathrm{~min}$ with the family. The purpose of the family sessions was to review the perspectives of parents, review the skills learnt in the young person's session, review family coping skills and review homework tasks.

Four $^{33-35} 37$ of the five depression interventions (for children with diabetes or IBD) included protocol modifications related to physical health. For example, all four included psychoeducation about the relationship between specific physical illnesses and mood. One $e^{34}$ also covered setting personal goals for diabetes self-care, diabetic barriers to behavioural activation and what to tell others about having diabetes. Martinović et al ${ }^{32}$ did not report any specific modifications for the physical health comorbidity (epilepsy).

\section{Anxiety interventions}

Anxiety protocols varied in format, although all were based on basic principles of CBT for anxiety (eg, cognitive restructuring and exposure exercises) and many used adapted versions of previously validated protocols. Four were delivered in a one-to-one format; one ${ }^{31}$ also added three parent sessions and one ${ }^{30}$ combined the results of an individual and group intervention.
Again, four of the studies adapted the intervention to account for the physical illness. Three 2931 related the material to illness-specific stressors (for IBD, diabetes and cystic fibrosis). In one, the intervention was particularly revised to account for the increased rates of learning problems found in children with epilepsy. ${ }^{27}$ Such alterations included longer sessions (to allow for a slower pace), additional written materials, more concrete language and a focus on behavioural rather than cognitive elements.

\section{Efficacy/effectiveness}

It is difficult to interpret the results of these studies as a whole, due to the large variety of methodologies, generally small sample sizes and variety of outcome measures. As the two $\mathrm{RCTs}^{32}{ }^{37}$ have the highest quality rating and least bias, we consider them to have the most valid and reliable results regarding efficacy. We note that there are no RCTs focused on anxiety.

Both trials demonstrated statistically significant results, with large effect sizes. In their depression treatment study, Szigethy et $a l^{37}$ state that they did not correct for Type 1 error, despite multiple comparisons, because 'the decision was made to err on the side of detecting versus not detecting a difference in treatment effect in this exploratory study'. In addition, a greater number of participants in the control group had their IBD rated as moderate/severe, compared with the intervention group. This means results may be confounded by illness severity.

All other studies demonstrated positive results for the interventions in terms of reductions in anxiety/depression, despite using different definitions of improvement (eg, presence of psychiatric disorder, change in clinical category or change on a symptom measure). Where analysis was undertaken, studies 
Table 1 Characteristics of anxiety studies

\begin{tabular}{|c|c|c|c|c|c|c|c|c|c|c|c|}
\hline Study & $\begin{array}{l}\text { Symptom of } \\
\text { mental } \\
\text { health } \\
\text { disorder }\end{array}$ & $\begin{array}{l}\text { Physical } \\
\text { health } \\
\text { condition }\end{array}$ & Intervention & Interventionist & $\begin{array}{l}\text { Type of } \\
\text { study }\end{array}$ & $\begin{array}{l}\text { Intervention location/ } \\
\text { practical } \\
\text { accommodations for } \\
\text { physical illness }\end{array}$ & $\begin{array}{l}\text { Participant } \mathbf{n} \\
\text { (\% female) }\end{array}$ & $\begin{array}{l}\text { Age of } \\
\text { participants } \\
\text { M years (SD) }\end{array}$ & $\begin{array}{l}\text { Time points for } \\
\text { measures/follow-up }\end{array}$ & $\begin{array}{l}\text { Global } \\
\text { quality } \\
\text { rating }\end{array}$ & Country \\
\hline Blocher et a $\left.\right|^{27}$ & Anxiety & Epilepsy & Computerised CBT & $\begin{array}{l}\text { Doctoral-level clinician, } \\
\text { master's-level clinician, } \\
\text { and bachelor's-level } \\
\text { research specialist }\end{array}$ & Pre-post & Medical care setting & $15(53 \cdot 3)$ & $11(1.51)$ & $\begin{array}{l}\text { Preintervention, } \\
\text { mid-intervention and } \\
\text { postintervention } \\
\text { 3-month follow-up }\end{array}$ & Moderate & USA \\
\hline Hains et al ${ }^{29}$ & Anxiety & Diabetes & $\begin{array}{l}\text { CBT } \\
\text { (stress-inoculation } \\
\text { programme) }\end{array}$ & $\begin{array}{l}\text { Doctoral students in } \\
\text { counselling psychology }\end{array}$ & $\begin{array}{l}\text { Multiple } \\
\text { baseline }\end{array}$ & Hospital & $6(50)$ & $\begin{array}{l}12,15,13,18, \\
13,14\end{array}$ & $\begin{array}{l}\text { Baseline (1-5 weeks } \\
\text { prior to intervention), } \\
\text { before each session, } \\
\text { 3-month follow-up }\end{array}$ & Moderate & USA \\
\hline Hains et $a l^{28}$ & Anxiety & Cystic Fibrosis & $\begin{array}{l}\text { CBT } \\
\text { (stress-inoculation } \\
\text { programme) }\end{array}$ & PhD psychologist & $\begin{array}{l}\text { Multiple } \\
\text { baseline }\end{array}$ & Participants' homes & $5(40)$ & $13-15$ years & $\begin{array}{l}\text { Baseline (2-5 weeks } \\
\text { prior to intervention), } \\
\text { before each session, } \\
\text { 3-month follow-up } \\
\text { Parent-report } \\
\text { preintervention, } \\
\text { mid-intervention and } \\
\text { at follow-up }\end{array}$ & Weak & USA \\
\hline $\begin{array}{l}\text { Papneja and } \\
\text { Manassis } \\
{ }^{30}\end{array}$ & Anxiety & Asthma & $\begin{array}{l}\text { Group and } \\
\text { individual } C B T\end{array}$ & $\begin{array}{l}\text { Various, including } \\
\text { psychology graduate } \\
\text { student, psychiatrists, child } \\
\text { youth worker, cognitive } \\
\text { therapist and cognitive } \\
\text { therapists in training }\end{array}$ & $\begin{array}{l}\text { Matched } \\
\text { case-control }\end{array}$ & $\begin{array}{l}\text { Anxiety disorders clinic of } \\
\text { a large urban children's } \\
\text { hospital }\end{array}$ & $\begin{array}{l}36+36 \\
\text { (control) } \\
\text { (gender not } \\
\text { stated) }\end{array}$ & $8-12$ years & $\begin{array}{l}\text { Preintervention and } \\
\text { postintervention }\end{array}$ & Strong & Canada \\
\hline Reigada et $a^{\beta 1}$ & Anxiety & $\begin{array}{l}\text { Inflammatory } \\
\text { bowel disease }\end{array}$ & $\begin{array}{l}\text { CBT (for parent and } \\
\text { child) }\end{array}$ & $\begin{array}{l}\text { PhD-level clinical } \\
\text { psychologist or advanced } \\
\text { doctoral students }\end{array}$ & Pre-post & $\begin{array}{l}\text { Sessions offered on same } \\
\text { day as medical } \\
\text { appointment/during } \\
\text { infusions. Sessions over } \\
\text { telephone also offered. }\end{array}$ & $9(44)$ & $13 \cdot 8(2 \cdot 2)$ & $\begin{array}{l}\text { Preintervention and } \\
\text { postintervention }\end{array}$ & Strong & USA \\
\hline
\end{tabular}

CBT, cognitive behavioural therapy. 
Table 2 Characteristics of depression studies

\begin{tabular}{|c|c|c|c|c|c|c|c|c|c|c|c|}
\hline Study & $\begin{array}{l}\text { Symptom of } \\
\text { mental } \\
\text { health } \\
\text { disorder }\end{array}$ & $\begin{array}{l}\text { Physical } \\
\text { health } \\
\text { condition }\end{array}$ & Intervention & Interventionist & $\begin{array}{l}\text { Type of } \\
\text { study }\end{array}$ & $\begin{array}{l}\text { Intervention } \\
\text { location/practical } \\
\text { accommodations for } \\
\text { physical illness }\end{array}$ & $\begin{array}{l}\text { Participant } \mathbf{n} \\
\text { (\% female) }\end{array}$ & $\begin{array}{l}\text { Age of } \\
\text { participants } \\
\text { M years (SD) }\end{array}$ & $\begin{array}{l}\text { Time points } \\
\text { for measures/ } \\
\text { follow-up }\end{array}$ & $\begin{array}{l}\text { Global } \\
\text { quality } \\
\text { rating }\end{array}$ & Country \\
\hline Martinović et $a l^{32}$ & $\begin{array}{l}\text { Subthreshold } \\
\text { depression }\end{array}$ & Epilepsy & $\begin{array}{l}\text { CBT vs TAU } \\
\text { (counselling) }\end{array}$ & $\begin{array}{l}\text { Qualified } \\
\text { therapists }\end{array}$ & $\begin{array}{l}\text { Randomised } \\
\text { controlled } \\
\text { trial }\end{array}$ & $\begin{array}{l}\text { Outpatient epilepsy } \\
\text { department }\end{array}$ & $15+15(60)$ & $\begin{array}{l}\text { BCl group: } \\
17 \cdot 2(2 \cdot 5) \\
\text { TAU: } 17 \cdot 6 \\
(2 \cdot 2)\end{array}$ & $\begin{array}{l}\text { Preintervention } \\
\text { and } \\
\text { postintervention } \\
\text { 9-month } \\
\text { follow-up }\end{array}$ & Strong & $\begin{array}{l}\text { Serbia and } \\
\text { Montenegro }\end{array}$ \\
\hline McGrady and Hood ${ }^{33}$ & $\begin{array}{l}\text { Subthreshold } \\
\text { depression }\end{array}$ & Diabetes & CBT & $\begin{array}{l}\text { Psychology } \\
\text { postdoctoral } \\
\text { fellow/doctoral } \\
\text { students }\end{array}$ & Pre-post & $\begin{array}{l}\text { Same hospital that } \\
\text { participants received } \\
\text { diabetes care } \\
\text { assessments }\end{array}$ & $9(33)$ & $15 \cdot 77(1.44)$ & $\begin{array}{l}\text { Preintervention } \\
\text { and } \\
\text { postintervention }\end{array}$ & Strong & USA \\
\hline Rosselló and Jiménez-Chafey ${ }^{34}$ & Depression & Diabetes & Group CBT & $\begin{array}{l}\text { Doctoral level } \\
\text { psychologists }\end{array}$ & Pre-post & Unclear & $11(82)$ & $14 \cdot 1(1 \cdot 3)$ & $\begin{array}{l}\text { Preintervention } \\
\text { and } \\
\text { postintervention }\end{array}$ & Moderate & Puerto Rico \\
\hline Szigethy et $a P^{35}$; Szigethy et $a^{36}$ & Depression & $\begin{array}{l}\text { Inflammatory } \\
\text { bowel disease }\end{array}$ & $\begin{array}{l}\text { Individual } \\
\text { CBT plus } \\
\text { family } \\
\text { sessions }\end{array}$ & $\begin{array}{l}\text { Psychiatrist } \\
\text { trained in } \\
\text { intervention }\end{array}$ & Pre-post & $\begin{array}{l}\text { Most sessions in } \\
\text { outpatient office. } \\
\text { Telephone sessions/ } \\
\text { covered two sessions } \\
\text { at once if session } \\
\text { missed. Sessions also } \\
\text { given during medical } \\
\text { procedures/ } \\
\text { hospitalisations }\end{array}$ & $11(64)$ & $14 \cdot 8(1 \cdot 7)$ & $\begin{array}{l}\text { Preintervention } \\
\text { and } \\
\text { postintervention } \\
6 \text {-month and } \\
\text { 12-month } \\
\text { follow-ups }\end{array}$ & Strong & USA \\
\hline Szigethy et $a l^{37} ;$ Thompson et a $\left.\right|^{38}$ & $\begin{array}{l}\text { Subthreshold } \\
\text { depression }\end{array}$ & $\begin{array}{l}\text { Inflammatory } \\
\text { bowel disease }\end{array}$ & $\begin{array}{l}\text { CBT vs TAU } \\
\text { plus } \\
\text { depression } \\
\text { information } \\
\text { leaflet }\end{array}$ & $\begin{array}{l}\text { Six trained } \\
\text { therapists (child } \\
\text { and adolescent } \\
\text { psychiatrists, child } \\
\text { and adolescent } \\
\text { psychologists, } \\
\text { clinical social } \\
\text { workers) }\end{array}$ & $\begin{array}{l}\text { Randomised } \\
\text { controlled } \\
\text { trial }\end{array}$ & $\begin{array}{l}\text { Maximum of three } \\
\text { sessions over the } \\
\text { telephone. } \\
\text { Face-to-face visits } \\
\text { coordinated with } \\
\text { medical visits/ } \\
\text { hospitalisations where } \\
\text { possible }\end{array}$ & $\begin{array}{l}22(54 \cdot 5)+19 \\
\text { (control; 47.5) }\end{array}$ & $\begin{array}{l}\text { PASCET: } \\
14 \cdot 95(2 \cdot 33) \\
\text { TAU: } 15 \cdot 02 \\
(1 \cdot 83)\end{array}$ & $\begin{array}{l}\text { Preintervention } \\
\text { and } \\
\text { postintervention } \\
\text { 9-month and } \\
\text { 12-month } \\
\text { follow-ups }\end{array}$ & Strong & USA \\
\hline
\end{tabular}


Table 3 Summary of recruitment and attrition

\begin{tabular}{|c|c|c|c|c|c|}
\hline Study & $\begin{array}{l}\text { Participants } \\
\text { invited }\end{array}$ & $\begin{array}{l}\text { Completed } \\
\text { screening } \\
\text { (\% invited) }\end{array}$ & $\begin{array}{l}\text { Met inclusion } \\
\text { criteria } \\
\text { (\% screened) }\end{array}$ & $\begin{array}{l}\text { Agreed to participate } \\
\text { ( } \% \text { of those meeting } \\
\text { inclusion criteria) }\end{array}$ & $\begin{array}{l}\text { Completed intervention } \\
\text { (\% agreed to } \\
\text { participate) }\end{array}$ \\
\hline Blocher et $a l^{27}$ & 149 & $29(19.5)$ & $20(69.0)$ & $18(90)$ & $15(83)$ \\
\hline Hains et $a l^{29}$ & 12 & NA & NA & 6 & $5(83)$ \\
\hline Hains et $a l^{28}$ & Unknown & NA & NA & 14 & $6(43.9)$ \\
\hline Martinović, et al ${ }^{32}$ & Unknown & 104 & 32 (at risk) & $32(100)$ & $30(93.8)$ \\
\hline McGrady and Hood ${ }^{33}$ & 219 & $24(10.0)$ & $16(0.67)$ & $13(81.3)$ & $10(76.9)$ \\
\hline Papneja and Manassis. ${ }^{30}$ & NA & NA & NA & NA & 36 matched pairs \\
\hline Reigada et $a l^{31}$ & 42 & $\begin{array}{l}21 *(50 .) \\
10+(58.8)\end{array}$ & $\begin{array}{l}17^{*}(81.0) \\
10+(100)\end{array}$ & $9(90)$ & $9(100)$ \\
\hline $\begin{array}{l}\text { Rosselló and } \\
\text { Jiménez-Chafey }\end{array}$ & 24 & $20(83.3)$ & $16(80)$ & $16(100)$ & $11(68.75)$ \\
\hline $\begin{array}{l}\text { Szigethy et } a l_{i}^{35} \\
\text { Szigethy et } a l^{3536}\end{array}$ & 168 & $\begin{array}{l}156^{*} \\
56 \dagger\end{array}$ & $\begin{array}{l}68^{*} \\
49+\end{array}$ & 41 & \\
\hline $\begin{array}{l}\text { Szigethy et } a l_{;}^{37} \\
\text { Thompson et } a l^{38}\end{array}$ & 121 & $\begin{array}{l}102^{*} \\
19 \dagger\end{array}$ & $\begin{array}{l}25^{*} \\
16 \dagger\end{array}$ & 11 & 11 \\
\hline
\end{tabular}

*Initial screening.

†Diagnostic interview.

NA, not applicable.

Table 4 Summary of results of anxiety studies

\begin{tabular}{|c|c|c|c|}
\hline Study & $\begin{array}{l}\text { Main study findings for mental health } \\
\text { outcome* }\end{array}$ & $\begin{array}{l}\text { Main study findings for physical health } \\
\text { outcome* }\end{array}$ & Other study outcomes* \\
\hline Blocher et $a l^{27}$ & $\begin{array}{l}\text { Significant reductions over time (baseline, } \\
\text { mid, post and 3-month follow-up) for: } \\
\text { Child-rated anxiety } \\
\text { Parent-rated total problem behaviours } \\
\text { Non-significant changes for: } \\
\text { Parent-rated internalising symptoms } \\
\text { Parent-rated child anxiety } \\
73 \% \text { of participants scored within } \\
\text { non-clinical range on child anxiety measure } \\
\text { post-treatment }\end{array}$ & None & $\begin{array}{l}\text { All parents were satisfied with the } \\
\text { computerised CBT intervention (agreeing } \\
\text { or strongly agreeing that the programme } \\
\text { was helpful for their child, and would } \\
\text { recommend to another parent). } \\
\text { All young people stated that the } \\
\text { programme was helpful in reducing } \\
\text { anxiety symptoms }\end{array}$ \\
\hline Hains et $a l^{28}$ & $\begin{array}{l}\text { Reductions in trait anxiety over } \\
\text { intervention for four of the five } \\
\text { participants, maintained at 3-month } \\
\text { follow-up }\end{array}$ & $\begin{array}{l}\text { Reductions in functional disability scores } \\
\text { post-treatment, although for two, the } \\
\text { score then increased again at 3-month } \\
\text { follow-up (one markedly so) }\end{array}$ & $\begin{array}{l}\text { Mean decrease in negative coping } \\
\text { strategies and an increase in positive } \\
\text { coping, but only for illness- (cystic } \\
\text { fibrosis) specific problems } \\
\text { Regarding general coping strategies, } \\
\text { negative coping strategies did not } \\
\text { change, and three young people } \\
\text { demonstrated reductions in positive } \\
\text { coping }\end{array}$ \\
\hline Hains et $a l^{29}$ & $\begin{array}{l}\text { Four out of the five young people scoring } \\
\text { at elevated levels of anxiety } \\
\text { preintervention demonstrated a reduction } \\
\text { in anxiety post-treatment, with gains } \\
\text { maintained (or improved upon) at the } \\
\text { 3-month follow-up }\end{array}$ & $\begin{array}{l}\text { Diabetes stress - varied response. Little } \\
\text { improvements made in most cases }\end{array}$ & $\begin{array}{l}\text { The two young people scoring at } \\
\text { elevated levels for anger expression } \\
\text { preintervention demonstrated reductions } \\
\text { in anger expression scores at the end of } \\
\text { treatment and at 3-month follow-up }\end{array}$ \\
\hline Papneja and Manassis. ${ }^{30}$ & $\begin{array}{l}\text { Significant reductions over time for: } \\
\text { Clinical Global Impression Scale score in } \\
\text { children with anxiety and asthma, and } \\
\text { children with anxiety alone } \\
\text { Non-significant trend for: } \\
\text { Less improvement in children with } \\
\text { comorbid anxiety and asthma }\end{array}$ & None & \\
\hline Reigada et $a l^{31}$ & $\begin{array}{l}\text { Self-reported general anxiety was } \\
\text { reduced (only descriptive statistics } \\
\text { provided) } \\
\text { Four participants did not meet criteria for } \\
\text { clinician-rated principle anxiety diagnosis } \\
\text { following the intervention }\end{array}$ & $\begin{array}{l}\text { Overall reduction in pain } \\
\text { Changes in disease severity were varied; } \\
50 \% \text { of participants had reduced disease } \\
\text { severity following the intervention, } 25 \% \\
\text { had the same and } 25 \% \text { had increased } \\
\text { disease severity }\end{array}$ & $\begin{array}{l}\text { Average parent satisfaction rating of } \\
\text { satisfied/very satisfied with the } \\
\text { intervention, they received very good/ } \\
\text { excellent care and they would } \\
\text { recommend the intervention to others } \\
\text { Young people felt that the therapist } \\
\text { cared a lot/very much and liked the } \\
\text { programme }\end{array}$ \\
\hline
\end{tabular}


reported a statistically significant benefit for at least one outcome. In interpreting the outcomes of these studies, we note that Szigethy et $a l^{36}$ offered additional sessions and/or psychotropic medications as necessary between end of treatment and follow-up. Gains at follow-up may not be due to the initial intervention alone. Tables 4 and 5 provide details on the main outcomes relating to mental health, physical health and other secondary outcomes.

Varied outcomes were demonstrated in relation to physical health measures. In general, where outcomes related to physical health showed significant improvement, these were related to subjective measures (eg, pain scales, self-reported selfmanagement); no consistent significant difference was found for objective measures of physical health, such as glycaemic control. $^{28} 293133-35$

\section{Practical adaptations for delivery within a physical healthcare setting}

Most studies made accommodations for young people who had a physical illness, and thus a number of medical appointments. For example, studies conducted sessions in participants' homes ${ }^{28}$ outpatient settings that were either attached to a hospital, or were in the hospital, ${ }^{29} 303233$ or in other medical care settings. $^{27}$

Studies of young people with IBD were particularly accommodating of medical appointments, through offering convenient time slots, telephone appointments and intervention locations. For example, appointments were coordinated with physical health appointments where necessary and some appointments were offered at the same time as a medical procedure (an infusion).

\section{Meta-analysis}

It was concluded that a meta-analysis would not be informative as there were only two RCTs, which reported different outcomes at different time points. The observational studies did not report appropriate data to undertake a meta-analysis. It was similarly not possible to fully investigate factors associated with the success of an intervention.

\section{DISCUSSION}

This review shows that children may benefit from cognitive behavioural interventions for depression and anxiety in the

Table 5 Summary of results of depression studies

\begin{tabular}{|c|c|c|c|}
\hline Study & $\begin{array}{l}\text { Main study findings for mental health } \\
\text { outcome* }\end{array}$ & $\begin{array}{l}\text { Main study findings for physical } \\
\text { health outcome* }\end{array}$ & Other study outcomes* \\
\hline Martinović et al ${ }^{32}$ & $\begin{array}{l}\text { Significantly greater decreases in scores for: } \\
\text { Self-reported depressive symptoms in CBI } \\
\text { group compared with TAU group } \\
\text { Differences retained at 9-month follow up } \\
\text { Non-significant difference for: } \\
\text { Number of depressive episodes between } \\
\text { groups ( } 3 \text { in TAU and } 0 \text { in CBI) }\end{array}$ & & $\begin{array}{l}\text { CBI group significantly greater quality of life } \\
\text { scores compared with TAU group, } \\
\text { postintervention and at 9-month follow-up }\end{array}$ \\
\hline McGrady and Hood ${ }^{33}$ & $\begin{array}{l}\text { Significant reductions for: } \\
\text { - Self-reports of depressive symptoms } \\
\text { - Parent reports of depressive symptoms }\end{array}$ & $\begin{array}{l}\text { Significant increase in self-reported } \\
\text { self-management levels } \\
\text { No significant change in } \\
\text { parent-reported self-management; } \\
\text { blood glucose monitor download; } \\
\text { glycaemic control } \\
\text { Seven out of nine participants } \\
\text { demonstrated increases in HbA1c } \\
\text { (ie, poorer glycaemic control) }\end{array}$ & \\
\hline $\begin{array}{l}\text { Rosselló and } \\
\text { Jiménez-Chafey }\end{array}$ & $\begin{array}{l}\text { Significant reductions for: } \\
\text { Self-reports of depressive symptoms } \\
\text { Non-significant reductions for } \\
\text { Anxiety and hopelessness }\end{array}$ & $\begin{array}{l}\text { Significant improvement in diabetes } \\
\text { self-efficacy over the course of } \\
\text { therapy } \\
\text { No significant changes in glycaemic } \\
\text { control, nor self-care behaviours }\end{array}$ & \\
\hline Szigethy et $a l^{35}$ & $\begin{array}{l}\text { Significant reductions for: } \\
\text { Self-reports of depressive symptoms } \\
\text { Parent reports of depressive symptoms } \\
\text { Maintained at both follow-up time points } \\
\text { (6 months and } 12 \text { months) }\end{array}$ & $\begin{array}{l}\text { No significant change in illness } \\
\text { severity postintervention } \\
\text { Significant increase in subjective } \\
\text { general health (child and } \\
\text { parent-report measures) } \\
\text { Mean increase in perceived physical } \\
\text { functioning (young person report } \\
\text { only; non-significant for } \\
\text { parent-report) }\end{array}$ & $\begin{array}{l}\text { Significant increase in perceived social } \\
\text { functioning (child and parent-report) } \\
\text { Mean overall satisfaction with the intervention } \\
\text { was } 6.64 \text { for parents and } 5.64 \text { for children, on a } \\
\text { scale of } 1-7 \text {, where } 7 \text { is the most helpful }\end{array}$ \\
\hline Szigethy et al ${ }^{37}$ & $\begin{array}{l}\text { Significantly greater changes in the intervention } \\
\text { group compared with control group for: } \\
\text { Reduction in self/parent-rated depression } \\
\text { severity (maintained at } 12 \text {-month follow-up). } \\
\text { Increases in global functioning } \\
\text { Non-significant changes for: } \\
\text { Reductions in the number of symptoms from } \\
\text { clinician-rated interview; greater reductions } \\
\text { were found in the intervention group, but this } \\
\text { difference was not statistically significant } \\
(p=0.055)\end{array}$ & & $\begin{array}{l}\text { CBT group increased in mean perceived control } \\
\text { score, whereas the comparison group } \\
\text { demonstrated a mean decrease. The difference } \\
\text { was maintained at the 6-month, but not at the } \\
12 \text {-month follow-up }\end{array}$ \\
\hline
\end{tabular}

*Significant refers to statistical significance at the 0.05 level. Results refer to pre-post treatment differences, unless stated otherwise.

$\mathrm{CBI}$, cognitive behavioural intervention. 
context of a comorbid chronic physical health problem. However, it also emerged that there is a significant lack of studies evaluating treatment of psychiatric symptoms in children and young people with chronic physical illnesses, despite 435 studies demonstrating their efficacy in otherwise healthy children. ${ }^{41}$ Methodologies, measures and methodological quality were variable, sample sizes were small and inclusion criteria differed, with studies investigating a variety of combinations of physical illness and psychiatric symptoms. This variability meant that a meta-analysis was not statistically appropriate and that the results are difficult to generalise.

While the significant results of all studies included in the search may represent an element of publication bias, full searches of trial databases were carried out prior to the review being undertaken. No currently running trials of interventions for common impairing psychiatric symptoms in children with long term conditions were found. Thus, it would appear that there is a true deficit in the literature, and that the available studies are representative of the little data available. It is possible that our search terms biased the findings towards cognitive behavioural interventions, however.

Specific adaptations to young people with a physical illness were generally included but were relatively minor and typically did not require significant specialist knowledge about the illness. Many child and adolescent mental health professionals are trained in the delivery of evidence-based cognitive behaviour therapies for anxiety and depression and therefore should be able to deliver these without significant additional training in paediatrics. Where specific information is needed to provide appropriate psychoeducation, Child and Adolescent Mental Health Service clinicians can liaise with the child's paediatrician.

Many studies made allowances for physical illness through the treatment location. Some studies allowed for the use of telephone sessions, sessions at home, or sessions at the same time/ venue as medical appointments, to reduce the burden on families. This more flexible approach was particularly seen in the IBD studies, ${ }^{31} 35$ which also showed good patient satisfaction. Clinically, a more flexible approach would be a step towards creating services that are more accessible for this population.

\section{Directions for future research}

Larger well controlled trials in the wider area of mental health interventions for children with physical illness are needed. Experimental studies are also needed since it is possible that some elevated level of anxiety regarding the physical illness may be beneficial and may contribute to good illness management. Existing studies have generally focused on adolescent populations and it would be useful to investigate the effects of interventions in younger age groups including disruptive behaviour. There were no studies of, for example, the efficacy of parenting programmes, a strongly evidence-based intervention for children with oppositional defiant disorder. Additional research to understand the effects of these interventions on physical health outcomes is also needed.

\section{CONCLUSIONS}

Together, these results suggest that it is possible to use evidencebased cognitive behavioural interventions to effectively treat anxiety and depressive symptoms in young people with chronic physical illnesses. Standard protocols developed for children and young people without physical illness can be used, with the same outcome measurement strategies. However, larger RCTs are needed. The results of this review suggest that this should ideally be a trial of a cognitive behavioural intervention, compared with treatment as usual. The cognitive behavioural intervention may need slight adaptation for use in children with physical illnesses-in particular flexibility around times and locations of appointments may be useful.

Acknowledgements The authors thank Professor Peter Bower and Dr Craig Whittington for their guidance in drafting the manuscript. The authors also thank $\mathrm{Mr}$ John Clarke for his advice regarding the search strategy.

Contributors $\mathrm{SB}, \mathrm{RS}, \mathrm{AC}$ and $\mathrm{IH}$ developed the search strategy. $\mathrm{AC}$ and $\mathrm{SB}$ ran the database searches and contacted researchers to identify relevant papers. $A C$ and $S B$ identified studies matching inclusion criteria; RS was consulted where there was disagreement or ambiguity regarding whether studies met inclusion criteria. SB and SW extracted data from the studies. AC and SB undertook quality analysis. RS, SB and $\mathrm{IH}$ drafted the manuscript. All authors read and approved the final manuscript.

\section{Competing interests None.}

Provenance and peer review Not commissioned; externally peer reviewed.

Open Access This is an Open Access article distributed in accordance with the Creative Commons Attribution Non Commercial (CC BY-NC 4.0) license, which permits others to distribute, remix, adapt, build upon this work non-commercially, and license their derivative works on different terms, provided the original work is properly cited and the use is non-commercial. See: http://creativecommons.org/ licenses/by-nc/4.0/

\section{REFERENCES}

1 Hysing M, Elgen I, Gillberg C, et al. Chronic physical illness and mental health in children. Results from a large-scale population study. J Child Psychol Psychiatry 2007:48:785-92.

2 Pinquart M, Shen Y. Behavior problems in children and adolescents with chronic physical illness: a meta-analysis. J Pediatr Psychol 2011;36:1003-16.

3 Green $\mathrm{H}$, McGinnity A, Meltzer $\mathrm{H}$, et al. Mental health of children and adolescents in Great Britain, 2004. London: ONS. The Stationery Office, 2005.

4 Lima NNR, do Nascimento VB, de Carvalho SMF, et al. Childhood depression: a systematic review. Neuropsychiatr Dis Treat 2013;9:1417.

5 Fergusson DM, Woodward L. Mental health, educational, and social role outcomes of adolescents with depression. Arch Gen Psychiatry 2002;59:225-31.

6 Hood KK, Huestis S, Maher A, et al. Depressive Symptoms in Children and Adolescents With Type 1 Diabetes Association with diabetes-specific characteristics. Diabetes Care 2006;29:1389-9.

7 Levine B-S, Anderson BJ, Butler DA, et al. Predictors of glycemic control and short-term adverse outcomes in youth with type 1 diabetes. J Pediatr 2001;139:197-203.

8 American Diabetes Association. Retinopathy in diabetes (Position Statement) Diabetes Care 2004;27(Supplement 1):S84-7.

9 Li S, Chen W, Srinivasan SR, et al. Childhood cardiovascular risk factors and carotid vascular changes in adulthood. JAMA 2003;290:2271-6.

10 de Araujo Filho GM, Yacubian EMT. Juvenile myoclonic epilepsy: psychiatric comorbidity and impact on outcome. Epilepsy Behav 2013;28:S74-80.

11 NHS Confederation. Investing in emotional and psychological wellbeing in people with long term conditions. Mental Health Network, 2012.

12 Centers for Disease Control and Prevention. Public Health Action Plan to Integrate Mental Health Promotion and Mental IIIness Prevention with Chronic Disease Prevention, 2011-2015. Atlanta: U.S. Department of Health and Human Services; 2011.

13 Butler AC, Chapman JE, Forman EM, et al. The empirical status of cognitive-behavioral therapy: a review of meta-analyses. Clin Psychol Rev 2006;26:17-31.

14 Ott D, Siddarth $\mathrm{P}$, Gurbani $\mathrm{S}$, et al. Behavioral disorders in pediatric epilepsy: unmet psychiatric need. Epilepsia 2003;44:591-7.

15 Katon WJ, Richardson L, Russo J, et al. Quality of mental health care for youth with asthma and comorbid anxiety and depression. Med Care 2006;44:1064-72.

15a Higgins JPT, Green S (editors). Cochrane Handbook for Systematic Reviews of Interventions Version 5.1.0 [updated March 2011]. The Cochrane Collaboration, 2011. Available from www.cochrane-handbook.org

16 American Psychiatric Association. Diagnostic and Statistical Manual-Text Revision (DSM-IV-TRim, 2000). American Psychiatric Association, 2000.

17 American Psychiatric Association. Diagnostic and statistical manual of mental disorders. 5th edn. Arlington, VA: American Psychiatric Publishing, 2013.

18 Yorke J, Fleming SL, Shuldham C. A systematic review of psychological interventions for children with asthma. Pediatr Pulmonol 2007;42:114-24.

19 van der Lee JH, Mokkink LB, Grootenhuis MA, et al. Definitions and measurement of chronic health conditions in childhood: a systematic review. JAMA 2007;297:2741-51.

20 Pless IB, Douglas JW. Chronic illness in childhood: Part I. Epidemiological and clinical characteristics. Pediatrics 1971;47:405-14. 
21 Perrin EC, Newacheck P, Pless IB, et al. Issues involved in the definition and classification of chronic health conditions. Pediatrics 1993;91:787-93.

22 Stein RE, Bauman LJ, Westbrook LE, et al. Framework for identifying children who have chronic conditions: the case for a new definition. J Pediatr 1993;122:342-7.

23 Sansom-Daly UM, Peate M, Wakefield CE, et al. A systematic review of psychological interventions for adolescents and young adults living with chronic illness. Health Psychol 2012;31:380.

24 Eccleston C, Palermo TM, Williams A, et al. Psychological therapies for the management of chronic and recurrent pain in children and adolescents. The Cochrane Library, 2014.

25 Jackson N, Waters E. Criteria for the systematic review of health promotion and public health interventions. Health Promot Int 2005;20:367-74.

26 Thomas $B$, Ciliska D, Dobbins $M$, et al. A process for systematically reviewing the literature: providing the research evidence for public health nursing interventions. Worldviews Evid Based Nurs 2004;1:176-84.

27 Blocher JB, Fujikawa M, Sung C, et al. Computer-assisted cognitive behavioral therapy for children with epilepsy and anxiety: a pilot study. Epilepsy Behav 2013;27:70-6.

28 Hains AA, Davies WH, Behrens D, et al. Cognitive behavioral interventions for adolescents with cystic fibrosis. J Pediatr Psychol 1997;22:669-87.

29 Hains AA, Davies WH, Parton E, et al. Brief report: a cognitive behavioral intervention for distressed adolescents with type I diabetes. J Pediatr Psychol 2001;26:61-6.

30 Papneja T, Manassis K. Characterization and treatment response of anxious children with asthma. Can J Psychiatry 2006;51:393-6.

31 Reigada LC, Benkov KJ, Bruzzese JM, et al. Integrating illness concerns into cognitive behavioral therapy for children and adolescents with inflammatory bowel disease and co-occurring anxiety. J Spec Pediatr Nurs 2013;18:133-43.
32 Martinović Ž, Simonović P, Djokić R. Preventing depression in adolescents with epilepsy. Epilepsy Behav 2006;9:619-24.

33 McGrady ME, Hood KK. Cognitive-behavioral therapy for adolescents with Type 1 diabetes and subclinical depressive symptoms. Diabetes Manag 2013;3:207-15.

34 Rosselló JM, Jiménez-Chafey MI. Cognitive-behavioral group therapy for depression in adolescents with diabetes: a pilot study. Interamerican J Psychol 2006:40:219-26.

35 Szigethy E, Whitton SW, Levy-Warren A, et al. Cognitive-behavioral therapy for depression in adolescents with inflammatory bowel disease: a pilot study. J Am Acad Child Adolesc Psychiatry 2004;43:1469-77.

36 Szigethy E, Carpenter J, Baum E, et al. Case study: longitudinal treatment of adolescents with depression and inflammatory bowel disease. J Am Acad Child Adolesc Psychiatry 2006;45:396-400.

37 Szigethy E, Kenney E, Carpenter J, et al. Cognitive-behavioral therapy for adolescents with inflammatory bowel disease and subsyndromal depression. J Am Acad Child Adolesc Psychiatry 2007;46:1290-8.

38 Thompson RD, Craig A, Crawford EA, et al. Longitudinal results of cognitive behavioral treatment for youths with inflammatory bowel disease and depressive symptoms. J Clin Psychol Med settings 2012;19:329-37.

39 March J, Silva S, Petrycki S, et al. Fluoxetine, cognitive-behavioral therapy, and their combination for adolescents with depression: Treatment for Adolescents With Depression Study (TADS) randomized controlled trial. JAMA 2004;292:807-20.

40 Weisz J, Moore P, Southam-Gerow M, et al. Therapist's manual: PASCET: primary and secondary control enhancement training program. Los Angeles: University of California, 1999.

41 Chorpita BF, Daleiden EL, Ebesutani C, et al. Evidence-based treatments for children and adolescents: an updated review of indicators of efficacy and effectiveness. Clin Psychol 2011;18:154-72. 